\title{
Osmotically Induced Volume and Turbidity Changes of Escherichia coli due to Salts, Sucrose and Glycerol, with Particular Reference to the Rapid Permeation of Glycerol into the Cell
}

\author{
By M. M. ALEMOHAMMAD AND C. J. KNOWLES \\ Biological Laboratories, University of Kent, Canterbury $\mathrm{CT}_{2}{ }_{7} \mathrm{NJ}$
}

(Received 20 August 1973)

SUMMARY

Increases in turbidity of Escherichia coli strain KI 2 due to added non-permeant salts $\left(\mathrm{NaCl}\right.$ and $\left.\mathrm{MgCl}_{2}\right)$ and sucrose are strictly dependent on medium osmotic pressure, when correction is made for changes in medium refractive index. The volume of the whole cell and the fraction of the intact cell bounded by the cytoplasmic membrane have been measured by dextran and $\left[{ }^{14} \mathrm{C}\right]$ sucrose exclusion spaces. Increases in medium osmotic pressure due to non-penetrant medium solutes cause outflow of water across the cytoplasmic membrane and contraction away from the cell wall (plasmolysis), corresponding to the increases in turbidity. In addition salts $\left(\mathrm{NaCl}\right.$ and $\left.\mathrm{MgCl}_{2}\right)$ cause appreciable contraction in volume of the whole cell, presumably due to ionic interaction with the wall; sucrose causes only marginal decreases in whole cell volume. Electron micrographs of cells plasmolysed by $\mathrm{NaCl}$ or $\mathrm{MgCl}_{2}$, but not by sucrose, show numerous adhesion points between the wall and the cytoplasmic membrane.

Glycerol penetrates the cell to the same extent as water, but because of its slower rate of penetration, transient decreases in volume occur which can be measured in a stopped-flow spectrophotometer due to concomitant increases in turbidity. In cells grown on glucose-containing medium the rate of glycerol penetration is non-saturating. In cells grown on glycerol an additional saturatingfacilitated diffusion system is induced. Mutants deleted in the facilitator $\left(\mathrm{F}^{-}\right)$are available and do not show facilitated diffusion when grown on glycerol. Water exit and glycerol penetration in glucose-grown cells show transition points in Arrhenius plots corresponding to phase changes of the membrane lipids.

\section{INTRODUCTION}

Cells are permeable to water, but selectively permeable to extra- and intra-cellular solutes. The cell permits entry and exit of only those solutes necessary to maintain its metabolism. Facilitated diffusion and active transport systems are formed to allow solute transport across the plasma membrane (Kaback, 1972). A few solutes, for example urea and glycerol, appear to be capable of entry by simple diffusion (Mitchell \& Moyle, 1956).

Cells thus act as osmometers: changes in medium osmotic pressure cause movements of water into or out of the cell (and hence cause volume changes of the cell) in order to regain osmotic equilibrium between the cell and its environment. A convenient, simple and rapid method of measuring osmotically-induced volume changes is to measure light scattering or turbidity changes. This technique is a powerful method of assaying substrate entry into cells. The medium osmotic pressure is raised, causing water exit and a decrease in volume (increase in turbidity). The subsequent entry of substrate causes re-swelling (decrease in turbidity) and the rate of re-swelling can be used to determine the properties of the substrate permea- 
tion system. This method has been utilized to study substrate transport in cells (Sen \& Widdas, I962) and organelles (Chappell \& Haarhoff, 1967) but has been little used in bacterial systems (Avi-dor, Kuczynski, Schatzberg \& Mager, I956; Mitchell \& Moyle, I956; Bovell, Packer \& Helgerson, I963).

Despite the rapid rate of glycerol entry into Escherichia coli by simple diffusion, Sanno, Wilson \& Lin (1968) have shown that E. coli can induce a facilitated diffusion for glycerol entry. The rate of glycerol entry, particularly in induced cells, was too rapid to be studied using a conventional spectrophotometer. This paper reports, as part of our studies into the effect of changes in osmotic and ionic environment on bacterial cells (Knowles \& Smith, I97I $a, b$; Knowles, I97I; Matts \& Knowles, 197I), some of the properties of glycerol permeation into $E$. coli measured in a stopped-flow spectrophotometer. Also presented are some data concerning the actual effect that is being measured by the turbidity changes and the validity of using turbidity changes to measure volume changes in $E$. coli.

\section{METHODS}

Bacterial strains and growth conditions. In addition to wild-type $E$. coli strain $\mathrm{KI} 2$, various mutant strains (obtained from Dr E. C. C. Lin) defective in the glycerol 3-phosphate (glp) regulon were used; the properties of these strains are given in Table 4 , using the nomenclature of Richey \& Lin (1972).

Unless otherwise stated, the wild-type strain was used, grown on $30 \mathrm{~mm}$-glucose plus M-9 salts (Miller, 1972). A $5 \mathrm{ml}$ inoculum of an overnight culture was added to $100 \mathrm{ml}$ fresh medium in a $250 \mathrm{ml}$ conical flask, and the culture grown to the end of the log phase (4 to $5 \mathrm{~h}$ ) at $35^{\circ} \mathrm{C}$ on a gyrotary shaker. Cells were harvested by centrifugation at $\mathrm{I} 2000 \mathrm{~g}$ for Io min at $4{ }^{\circ} \mathrm{C}$, washed once in Io mM-imidazole- $\mathrm{HCl}$ buffer $(\mathrm{pH} 7.0)$ and resuspended in the same buffer. Larger quantities of cells were grown in eight $600 \mathrm{ml}$ quantities in 21 conical flasks.

Alternative media, where stated, were 30 mm-glycerol plus M-9 salts, I \% Casamino acids, and I \% Casamino acids plus Io mM-glycerol 3-phosphate. Growth conditions were exactly as given above.

Total turbidity changes. These were measured in a conventional spectrophotometer at $700 \mathrm{~nm}$. Cells were suspended in $2.8 \mathrm{ml}$ Io mM-imidazole buffer ( $\mathrm{pH} 7.0$ ) in a I cm cuvette at room temperature $\left(2 \mathrm{I} \pm 2{ }^{\circ} \mathrm{C}\right)$ at an absorbance of about 0.2 absorbance units. Buffer $(0.2 \mathrm{ml})$, or buffer plus $\mathrm{NaCl}, \mathrm{MgCl}_{2}$, sucrose, glycerol or Ficoll to give the desired final solute concentration, were added and the mixture shaken. The absorbance was read 2 min after mixing.

Turbidity effects were measured at $700 \mathrm{~nm}$ as this wavelength had been used in previous studies. Following the use of the stopped-flow spectrophotometer at $550 \mathrm{~nm}$, some of these experiments were repeated at $550 \mathrm{~nm}$ with similar results to those given in this paper.

Kinetics of turbidity changes. The kinetics of the turbidity changes were measured in a stopped-flow spectrophotometer. This instrument differed from the classical design of Gibson \& Milnes (1964) in that there was no terminating syringe. The pair of driving syringes were arrested by hitting a rigid block which incorporated a microswitch to activate the recording system. Outflow of the solution from the observation tube was partially restricted by having a limited-diameter exit tube; this method prevented the artifactual volume changes due to pressure shock that have been observed by others (Blum \& Forster, 1970; Lovett, I965). A complete description of the apparatus will be presented elsewhere (B. H. Robinson, personal communication). 
The apparatus was operated in the transmission mode, using a 2 mm-path-length observation tube. Changes in transmittance were measured at $550 \mathrm{~nm}$ (band width $4 \mathrm{~nm}$ ) since the output from the optical system was optimal at this wavelength. E. coli, suspended in Io mMimidazole buffer ( $\mathrm{pH} \mathrm{7.0)}$ to an absorbance of 2.0 (in a I cm cuvette) was mixed with an equal volume of $\mathrm{NaCl}, \mathrm{MgCl}_{2}$ or glycerol in buffer, and the change in transmittance displayed on a storage oscilloscope. The traces were photographed, enlarged on to graph paper and converted to absorbance using the Beer-Lambert law. The change in transmittance observed on mixing bacteria suspended in buffer with additional buffer was negligible.

Measurement of cell spaces. Scherrer \& Gerhardt (1971) have shown that polyglycols or dextrans of molecular weight greater than about $10^{5}$ are unable to penetrate the cell wall of Bacillus megaterium. With reducing size, sugars and glycols are increasingly able to penetrate the wall, whilst those smaller in size than stachyose are able to penetrate the cytoplasmic membrane. Experiments to measure exclusion spaces using Sephadex marker blue dextran 2000 with an average molecular weight of $2 \times 10^{6}$ (cf. leaflet 'Blue Dextran 2000', from Pharmacia Ltd) and stachyose can be used to determine the whole cell and 'protoplast' volumes respectively. Experiments with $E$. coli (Alemohammed and Knowles, unpublished observations) have shown that it is possible to measure exclusion spaces in a similar manner in this bacterium. Unfortunately stachyose is too expensive to use routinely, but the slightly smaller sucrose can be used with essentially no difference in results.

An $18 \mathrm{ml}$ portion of $E$. coli suspended in Io mM-imidazole buffer, $\mathrm{pH} 7.0$ ( \pm medium solute) was added to a tared centrifuge tube and centrifuged at $38000 \mathrm{~g}$ for $20 \mathrm{~min}$ at $4{ }^{\circ} \mathrm{C}$. The supernatant was discarded, and the inside of the tube carefully wiped with a tissue and then re-weighed. The initial concentration of cells was such that the pellet weight was $I \cdot 2$ to I. 8 g. Marker blue dextran ( $0.5 \mathrm{ml} ; 2 \%$, w/v) in Io mM-imidazole buffer $(\mathrm{pH} 7.0)$, $0.1 \mathrm{ml}$ of uniformly labelled $\left[{ }^{14} \mathrm{C}\right]$ sucrose (to give a final concentration of $3 \mathrm{mM}$ and Io000 to 20000 c.p.m.) and $0.3 \mathrm{ml}$ of Io mM-imidazole buffer, $\mathrm{pH} 7.0$ ( \pm medium solute to give a final concentration equivalent to that initially used) were added and the solution carefully mixed. After $10 \mathrm{~min}$ at $4{ }^{\circ} \mathrm{C}$ the mixture was centrifuged at $38000 \mathrm{~g}$ for $20 \mathrm{~min}$ at $4{ }^{\circ} \mathrm{C}$ (or filtered on a $0.45 \mu \mathrm{m}$ Millipore filter). The dextran concentration was assayed by measuring the absorbance of a suitable dilution at $620 \mathrm{~nm}$. The $\left[{ }^{14} \mathrm{C}\right]$ sucrose concentration was measured by addition of $0.1 \mathrm{ml}$ of the supernatant to $10 \mathrm{ml}$ of scintillation fluid (Bray, I960) and counting in a scintillation counter. The experiment was done in triplicate for each condition and the average taken. Control dilutions of the $\left[{ }^{14} \mathrm{C}\right]$ sucrose and dextran were done exactly as above but using $\mathrm{I} 8 \mathrm{ml}$ of buffer.

Black \& Gerhardt (I962) have shown that solute uptake into the pellet, the solute 'space', can be evaluated using the equation:

$$
S^{\mathrm{w}}=\frac{V_{\mathrm{s}}}{W_{\mathrm{p}}}\left(\frac{C_{0}}{C_{\mathrm{f}}}-\mathrm{I}\right)
$$

where $S^{\mathrm{w}}$ is the space or fraction of the pellet penetrated by the solute. This includes the extracellular (interstitial) space as well as the fraction of the cell penetrated. The superscript 'w' in $S^{\mathrm{w}}$ refers to the fact that the weight $\left(W_{\mathrm{p}}\right)$ rather than volume of the pellet is measured. Since the density of $E$. coli is I. .07 to I. $.08 \mathrm{~g} / \mathrm{ml}$ (cf. Black \& Gerhardt, I962), weight measurements are essentially an index of volume. $V_{B}$ is the volume of the added $\left[{ }^{14} \mathrm{C}\right]$ sucrose and dextran of initial and final concentrations $C_{0}$ and $C_{\mathrm{f}}$ respectively.

The fraction of the cell penetrated by the solute, $R^{\mathrm{w}}$, is given by:

$$
R^{\mathrm{w}}=\frac{S_{\mathrm{sol}}^{\mathrm{w}}-S_{\mathrm{in}}^{\mathrm{w}}}{\mathrm{I}-S_{\mathrm{in}}^{\mathrm{w}}},
$$


Table I. Experimental results and calculation of exclusion spaces of E. coli suspended in dilute buffer, buffer $+\mathrm{NaCl}$, or buffer + glycerol

Pellet weight, $W_{\mathrm{p}}(\mathrm{g})$

$\left[{ }^{14} \mathrm{C}\right]$ sucrose concentration, $C_{\mathrm{f}}$ (c.p.m.)

Dextran 2000 concentration, $C_{1}\left(A_{620}\right)$

Sucrose space, $S_{\text {sucrose }}^{\mathrm{w}}$

Dextran space, $S_{\text {dextran }}^{*}$

Cell volume, $W$ (cells)

'Protoplast' volume, W('protoplast')

$W($ cells $)(\%)^{*}$

$W\left(\right.$ 'protoplast') $(\%)^{*}$

$R^{\mathrm{w}}$ (sucrose) as $\%$ cell volume

Suspension medium

\begin{tabular}{|c|c|c|}
\hline $\begin{array}{l}\text { Io mM imidazole } \\
\text { buffer }(\mathrm{pH} 7 \cdot 0)\end{array}$ & $\begin{array}{l}+0.2 \mathrm{M} \\
\mathrm{NaCl}\end{array}$ & $\begin{array}{l}+0.34 \mathrm{M} \\
\text { glycerol }\end{array}$ \\
\hline $\mathrm{I} \cdot 504$ & I.293 & I $\cdot 57$ I \\
\hline 12120 & 11820 & 12210 \\
\hline 0.261 & 0.266 & 0.259 \\
\hline 0.424 & 0.523 & 0.399 \\
\hline 0.149 & 0.157 & 0.148 \\
\hline $1 \cdot 280$ & I.092 & $1 \cdot 339$ \\
\hline 0.867 & 0.617 & 0.944 \\
\hline 100 & 85.4 & $104 \cdot 8$ \\
\hline 100 & $7 \mathrm{I} \cdot 3$ & $109 \cdot 0$ \\
\hline $32 \cdot 3$ & 43.4 & $29 \cdot 5$ \\
\hline
\end{tabular}

Initial $\left[{ }^{14} \mathrm{C}\right]$ sucrose concentration $\left(C_{0}\right)$ was $3 \mathrm{~mm}$ and 30705 c.p.m. Initial dextran 2000 concentration $\left(C_{0}\right)$ was equivalent to an absorbance of 0.326 at $620 \mathrm{~nm}$.

* Compared to the volume of the cell and 'protoplast' when suspended in buffer only.

where $S_{\mathrm{sol}}^{\mathrm{w}}$ is the fraction of the pellet space penetrated by a particular solute and $S_{\mathrm{in}}^{\mathrm{w}}$ is the interstitial space. As dextran 2000 does not penetrate the cell, $S_{\mathrm{in}}^{\mathrm{w}}=S_{\mathrm{dextran}}^{\mathrm{w}}$ and:

$$
R^{\mathrm{w}}=\frac{S_{\mathrm{sol}}^{\mathrm{w}}-S_{\mathrm{dextran}}^{\mathrm{w}}}{\mathrm{I}-S_{\text {dextran }}^{\mathrm{w}}}
$$

If $S_{\mathrm{sol}}^{\mathrm{w}}$ for sucrose $\left(S_{\mathrm{sucrose}}^{\mathrm{w}}\right)$ is measured the value $R^{\mathrm{w}}$ (sucrose) can be obtained, which is a measure of the cell wall volume, or, in plasmolysed cells, the wall volume plus plasmolytic space. The weight of the cell $(\approx$ volume) can be obtained from the equation:

and for the 'protoplast':

$$
W(\text { cell })=W_{\mathrm{p}}\left(\mathrm{I}-S_{\text {dextran }}^{\mathrm{w}}\right)
$$

$$
W(\text { 'protoplast' })=W_{\mathrm{p}}\left(\mathrm{I}-S_{\mathrm{sucrose}}^{\mathrm{w}}\right)
$$

The results of a typical experiment and a sample calculation are given in Table I.

Packed cell volumes. Packed cell volumes were measured by the haematocrit method. Washed cell suspensions in Io mM-imidazole buffer, $\mathrm{pH} 7 \cdot 0$ ( \pm solute) at about $50 \mathrm{mg}$ dry $w t / m l$ were drawn into a $7.5 \mathrm{~cm}$ capillary tube to a height of about $6 \mathrm{~cm}$. The tube was sealed by pressing the dry end into Cristaseal (Hawksley and Sons Ltd, Lancing, Sussex). Batches of twelve tubes were centrifuged at $2000 \mathrm{~g}$ for $60 \mathrm{~min}$ at $4{ }^{\circ} \mathrm{C}$ in a horizontal head fitted to a MSE Minor centrifuge (Measuring and Scientific Equipment Ltd, London). The packed cell volumes were determined from the pellet column height as a fraction of the total pellet plus medium column height using an MSE haematocrit protractor. The experiment was done in quadruplicate for each condition and the average taken.

Electron microscopy. Samples $(4 \mathrm{ml}$; $10 \mathrm{mg}$ dry wt/ml) of E. coli suspended in $10 \mathrm{~mm}-$ imidazole buffer ( $\mathrm{pH} \mathrm{7.0)}$ ) at room temperature were mixed with I $\mathrm{ml}$ buffer, or buffer plus $\mathrm{NaCl}$ (final concentration $0.2 \mathrm{M}$ ), $\mathrm{MgCl}_{2}(0.14 \mathrm{M})$, glycerol (0.34 M) or sucrose (0.3 M). After I min incubation they were fixed by injection of $5 \mathrm{ml}$ of $3 \%$ glutaraldehyde (made up in the appropriate solute solution). Samples were centrifuged at $4000 \mathrm{~g}$ for ro min at room temperature, washed four times in solute solution and finally suspended in $0.5 \mathrm{ml} \mathrm{r} \% \mathrm{OsO}_{4}$. After I $\mathrm{h}$ the solutions were washed three times in the correct solute solution and finally suspended in I $\mathrm{ml}$ solute solution. This was mixed with I $\mathrm{ml} 3 \%$ agar at $60{ }^{\circ} \mathrm{C}$. The solidified 
agar was cut into I mm cubes, washed in distilled water and dehydrated through a gradual series of ethanolic solutions. Final dehydration was in absolute ethanol. After overnight incubation in a $30 \%$ solution of Spurr's (1969) resin in ethanol, they were taken through three changes of resin ( $8 \mathrm{~h}$ each) and finally embedded in fresh resin by overnight polymerization at $70^{\circ} \mathrm{C}$. Silver sections were cut on an LKB Ultratome III, mounted on Formvarcoated copper grids and stained with $5 \%$ uranyl acetate in $\mathrm{I} \%$ acetic acid at $60{ }^{\circ} \mathrm{C}$ for $30 \mathrm{~min}$, followed by alkaline lead citrate (Reynolds, 1963 ) for $5 \mathrm{~min}$ at room temperature. Sections were examined in an AEI EM80IA electron microscope, operating at $60 \mathrm{kV}$.

Other methods. Refractive indices were measured in degrees using an Abbe refractometer (high accuracy, degree scale model 60/ED, Bellingham \& Stanley, London) and a sodium lamp $\left(D_{1}\right.$ line, $\left.589.6 \mathrm{~nm}\right)$. Osmotic pressures were measured in a freezing-point osmometer (model $3 \mathrm{~L}$, Advanced Instruments, Newton Highlands, Massachusetts, U.S.A.). Media of high osmotic pressure (365 m-osm) routinely used were $0.2 \mathrm{M}-\mathrm{NaCl}, 0.14 \mathrm{M}-\mathrm{MgCl}_{2}, 0.3 \mathrm{M}-$ sucrose and $0.34 \mathrm{M}$-glycerol in Io mM-imidazole buffer $(\mathrm{pH} 7 \cdot 0)$. Low osmotic pressure medium (2I $\mathrm{m}$-osM) was provided by buffer alone.

Chemicals. Ficoll and dextran 2000 were obtained from Pharmacia Ltd and imidazole (grade III) was supplied by Sigma Chemical Co. All other chemicals were the finest grade available and all solutions were made up in distilled water.

\section{RESULTS}

\section{Turbidity increases}

We have previously shown that increases in medium osmotic pressure due to nonpermeant solutes cause decreases in volume of $E$. coli and that these decreases in volume can be measured as increases in turbidity (Knowles, 197I). Surprisingly, the turbidity changes were strictly dependent on medium osmolality, despite the fact that ions cause a contraction in volume of the whole cell including the wall, whilst non-electrolytes cause only a decrease in the 'protoplast'* volume (plasmolysis only). Furthermore, since some divalent cations are bound to bacterial cell walls (Eagon, 1969; Tempest, Dicks \& Meer, 1967), it might be expected that there would be small differences in the effects caused by monovalent and divalent ions.

As most solutes cause small changes in medium refractive index we have re-examined the osmotically-induced turbidity changes of $E$. coli, correcting for changes in medium refractive index, to see if there are in fact slight differences in turbidity increments induced by different solutes.

Since Ficoll has a high refractive index but, due to its high molecular weight, has little effect on the medium osmotic pressure (cf. leaflet 'Ficoll for Cell Research', from Pharmacia Ltd), corrections can be made for changes in medium refractive index. The decrease in turbidity of a cell suspension on addition of Ficoll, giving an equivalent refractive index change to that of a particular concentration of a given solute, can be added to the increase in turbidity observed on addition of the solute. There is thus a correction for the change in medium refractive index caused by the solute. Figure I ( $a$ ) shows such a curve obtained by correcting for the change in refractive index due to sucrose, and referring to standard curves for the actual changes in refractive index of the medium alone with increasing concentrations of sucrose and Ficoll (Fig. I $b$ ).

\footnotetext{
* In this paper the term 'protoplast' will be used to refer to that part of the whole cell bounded by the cytoplasmic membrane, and does not imply that protoplasts, devoid of cell wall components, are being used.
} 

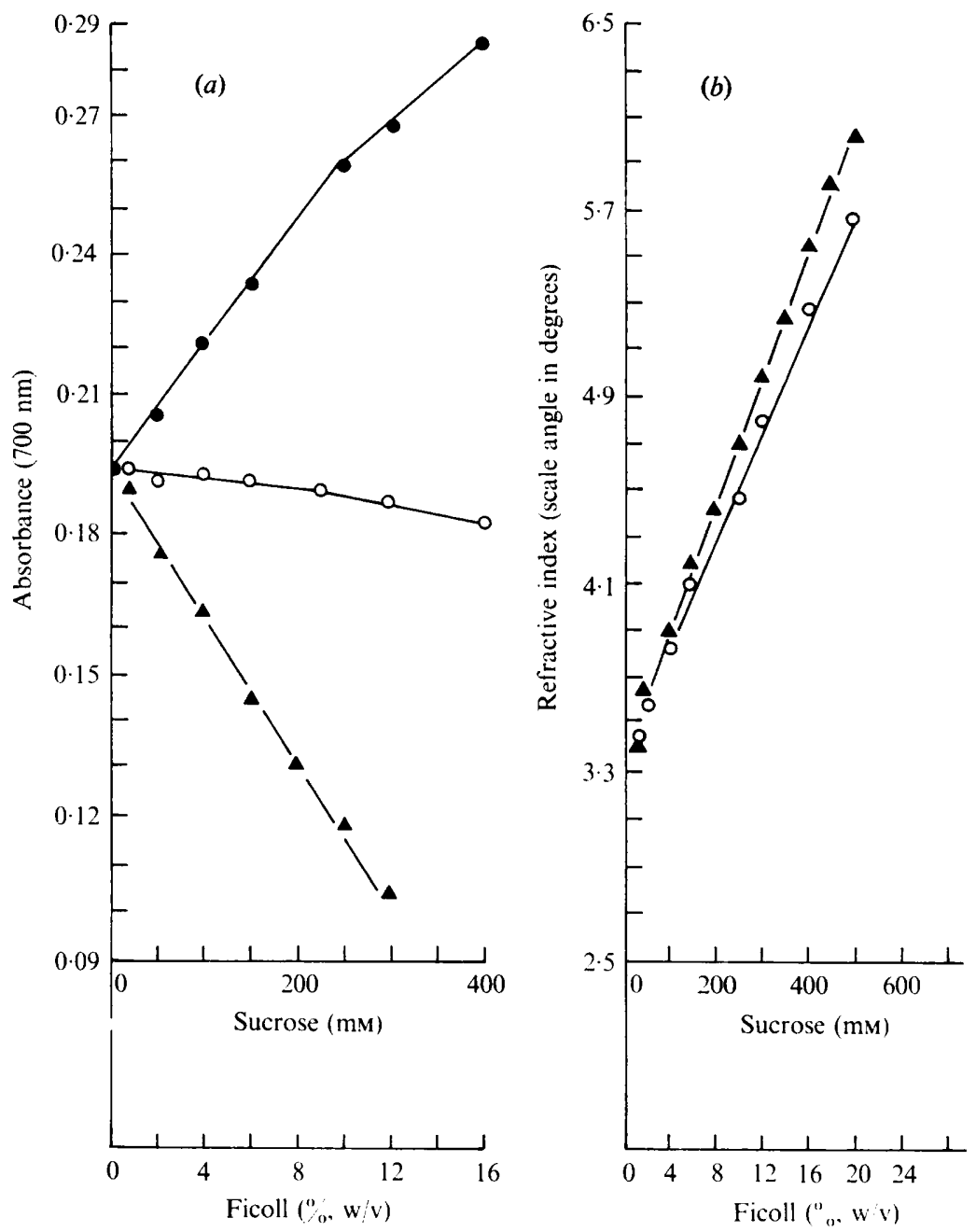

Fig. 1. The observed change in turbidity of $E$. coli caused by sucrose solutions and corrections for changes in medium refractive index. $E$. coli suspended in $10 \mathrm{mM}$-imidazole buffer $(\mathrm{pH} 7 \cdot 0)$ was mixed with Ficoll or sucrose solutions and the absorbance measured at $700 \mathrm{~nm}$ in a $1 \mathrm{~cm}$ cuvette $2 \mathrm{~min}$ after mixing (a). The observed change in absorbance due to sucrose ( $O$ ) was corrected (O) for changes in medium refractive index by the addition of the decrease in absorbance seen on addition of Ficoll $(\boldsymbol{\Delta})$ giving a similar refractive index of the medium. This was found by reference to calibration curves $(b)$. These were obtained by measuring the refractive indices of sucrose $(O)$ and Ficoll ( $\Delta$ ) solutions in $10 \mathrm{~mm}$-imidazole.

Figure 2 shows corrected increases in turbidity obtained on addition of sucrose or monovalent $(\mathrm{NaCl})$ or divalent $\left(\mathrm{MgCl}_{2}\right)$ cations to a dilute suspension of $E$. coli in weak buffer. The increases in turbidity are dependent on the medium osmotic pressure and the curve obtained does not markedly differ from the uncorrected curves due to added salts (Knowles, I97I). The refractive index increments due to $\mathrm{NaCl}, \mathrm{MgCl}_{2}$ and glycerol are small and were not expected to have a large effect. On the other hand, the refractive index increment due to sucrose is much larger; the corrected curve due to sucrose exactly fits the curve corresponding to the salts. 


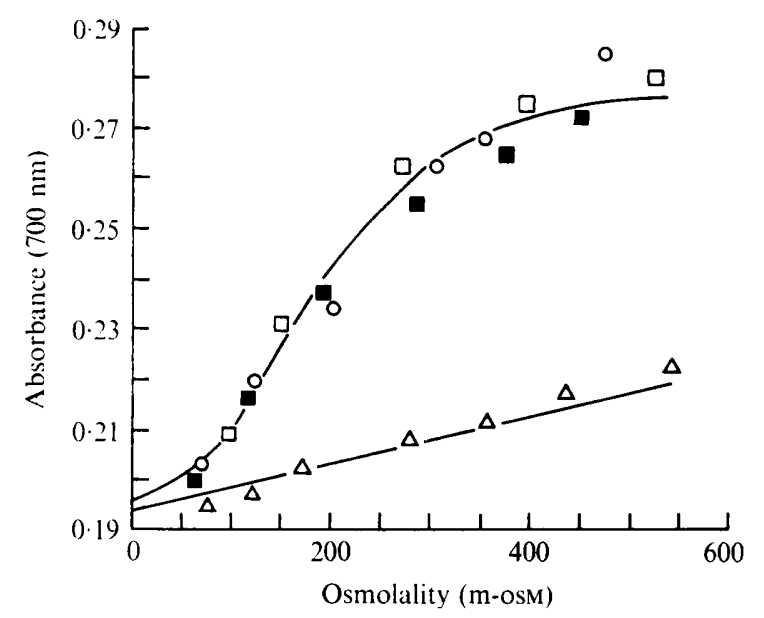

Fig. 2. The increase in turbidity of E. coli on addition of $\mathrm{NaCl}(\square), \mathrm{MgCl}_{2}(\square)$, sucrose (O) or glycerol $(\triangle)$ after correction for changes in medium refractive index.

Glycerol, to which E. coli is highly permeable (see below), causes little overall increase in turbidity.

\section{Electron micrographs}

Under the phase contrast microscope it can be seen that, on addition of non-penetrant salts $\left(\mathrm{NaCl}\right.$ or $\left.\mathrm{MgCl}_{2}\right)$ or sucrose, plasmolysis (contraction of the cytoplasmic membrane away from the wall) occurs. In the case of the permeant glycerol no plasmolysis can be seen. If, however, a drop of a concentrated glycerol solution is added to the side of the slide whilst looking down the microscope, the cells appear to 'shudder'. Due to the rapidity of the effect it is difficult to tell whether or not this is due to transient plasmolysis.

Figure 3 shows electron micrographs of negatively stained sections of $E$. coli cells fixed under different osmotic conditions. In cells fixed when suspended in Io mM-imidazole buffer ( $\mathrm{pH} 7.0$ ) (Fig. $3 a$ ) or buffer plus 0.35 M-glycerol (Fig. $3 b$ ) no plasmolysis is seen and the cytoplasmic membrane is in continuous close contact with the cell wall. In cells fixed in the presence of $0.2 \mathrm{M}-\mathrm{NaCl}$ (Fig. $3 c$ ) or $0.14 \mathrm{M}-\mathrm{MgCl}_{2}$ (not shown) plasmolysis occurs. The cytoplasmic membrane is contracted away from the cell wall, and the murein layer remains associated with the wall. Numerous points of contact remain between the wall and membrane, giving a 'loop' effect. Sucrose also causes plasmolysis with contraction from either both sides (Fig. $3 d$ ) or the end(s) of the cell (Scheie, I969). The occurrence of the numerous points of contact between the cell wall and the cytoplasmic membrane seen by plasmolysis with $\mathrm{NaCl}$ and $\mathrm{MgCl}_{2}$ do not occur in plasmolysis owing to sucrose; they appear to depend on the ionic strength of the medium.

\section{Volume measurement}

Previous measurements of the cell volume of $E$. coli were made by an adaptation of the method of Mitchell \& Moyle (I956). This technique requires extremely thick suspensions of cells and is relatively insensitive. We have therefore used the more accurate method of Black \& Gerhardt (I962) to measure the effect of changes of medium osmotic pressure on cell size (dextran space) and 'protoplast' size (sucrose space). 

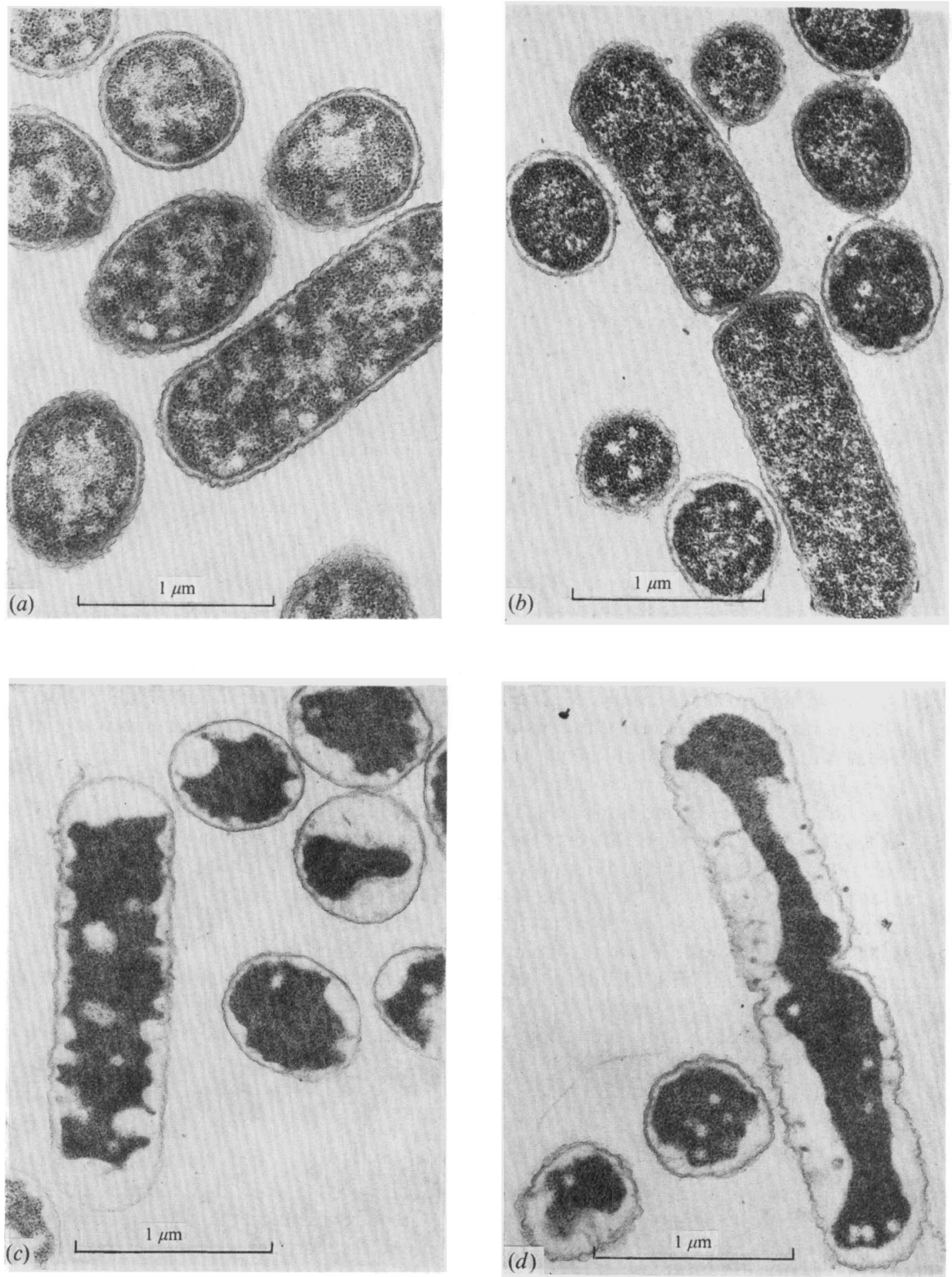

Fig. 3. Electron micrographs of $E$. coli in Io mM-imidazole buffer ( $\mathrm{pH} 7.0)(a)$, or buffer plus 0.34 M-glycerol $(b), 0.2 \mathrm{M}-\mathrm{NaCl}(c)$, or $0.3 \mathrm{M}$-sucrose $(d)$. 
Table 2. The variation in cell volume and 'protoplast' volume of E. coli suspended in $10 \mathrm{mM}$-imidazole buffer ( $\mathrm{pH} 7.0)$ with added salts, sucrose and glycerol

$\begin{array}{lrc}\begin{array}{c}\text { Additions } \\ (365 \mathrm{~m}-\mathrm{osm})\end{array} & \text { 'Protoplast' volume } & \begin{array}{c}\text { Cell volume } \\ (\%)\end{array} \\ \text { No additions } & (\%) & 100 \\ \text { 0.20 M- } \mathrm{NaCl} & 100 & 8 \mathrm{I} \\ 0.14 \mathrm{M}-\mathrm{MgCl}_{2} & 67 & 84 \\ 0.30 \mathrm{M} \text {-sucrose } & 68 & 9 \mathrm{I} \\ 0.34 \mathrm{M} \text {-glycerol } & 70 & \text { IOI }\end{array}$

The 'protoplast' volumes were measured by the $\left[{ }^{14} \mathrm{C}\right]$ sucrose spaces and the cell volumes by the dextran spaces. The results given are each the average of six experiments of the type detailed in Table $I$.

Table 2 shows that increasing the medium osmotic pressure by equiosmolal concentrations of $\mathrm{NaCl}, \mathrm{MgCl}_{2}$ or sucrose caused a 30 to $35 \%$ shrinkage in 'protoplast' volume. In addition the salts caused a 15 to $20 \%$ shrinkage in volume of the whole cell, whilst the nonelectrolytic sucrose caused only a small (5 to $10 \%$ ) decrease in volume. The fraction of the cell penetrated by $\left[{ }^{14} \mathrm{C}\right]$ sucrose $\left(R^{\mathrm{w}}\right.$ for sucrose) was 26 to $34 \%$ in cells suspended in buffer. This space represents the volume of the cell wall. In cells suspended in salts $(0.2 \mathrm{M}-\mathrm{NaCl}$ or $0.14 \mathrm{M}-\mathrm{MgCl}_{2}$ ) this space increased to 40 to $45 \%$ of the cell volume and in sucrose it was 43 to $47 \%$ of the cell volume. This increase in wall space is due to contraction of the cytoplasmic membrane away from the cell wall and the presence of the plasmolytic space.

The minimum period of exposure of the cell to the added solutes in these experiments was about $50 \mathrm{~min}$. This can be reduced to about $30 \mathrm{~min}$, if the suspensions are filtered rather than centrifuged, with no effect on the measured volumes. The changes in turbidity (Fig. 2) are stable for at least $\mathrm{I} h$.

The penetrant glycerol caused no shrinkage in volume (Table 2) or increase in turbidity (Fig. 2). Indeed, a small but consistent ( 2 to $10 \%$ ) increase in both 'protoplast' and cell volumes was observed. This could be due to protein relaxation. Three experiments, using $3 \mathrm{mM}-\left[{ }^{14} \mathrm{C}\right]$ glycerol, to determine the proportion of the cell penetrated by glycerol $\left(R^{\mathrm{w}}\right.$ for glycerol), gave values of 68,66 , and $67 \%$ for cells suspended in Io mM-imidazole buffer ( $\mathrm{pH} \mathrm{7.0).} \mathrm{In} \mathrm{three} \mathrm{experiments,} \mathrm{the} \mathrm{proportions} \mathrm{of} \mathrm{the} \mathrm{cell} \mathrm{volume} \mathrm{penetrated} \mathrm{by} \mathrm{tritiated}$ water were 69,70 and $73 \%$. The remaining $30 \%$ of the cell volume inaccessible to water is due to the physical volume of the cellular constituents. The close similarity in the proportion of the cell accessible to glycerol and to water confirms the ready permeability of the cell to glycerol.

Measurement of packed cell volumes (haematocrits) gives values for the volume of the cells plus interstitial space. Provided that the cell shape does not change when its volume varies, which would affect the relative interstitial space, packed cell volume measurements are a simple way of estimating whole cell volumes. Table 3 shows that in dilute buffer, or buffer plus salts, sucrose or glycerol volume changes in good agreement with the values obtained from dextran space measurements (Table 2) were obtained.

\section{Turibidity changes due to glycerol entry}

The kinetics of the turbidity changes of $E$. coli, as well as the total increases in turbidity, are dependent on the osmolality of the added solute (Matts \& Knowles, I97I ; Fig. 2). When the added solute is glycerol there is little increase in turbidity if measured in the period 2 to 
Table 3. The variation in packed cell volume of E. coli suspended in $10 \mathrm{mM}$-imidazole buffer $(\mathrm{pH} 7 \cdot 0)$ with added salts, sucrose and glycerol

$\begin{array}{lc}\begin{array}{c}\text { Additions } \\ \text { (365 m-osm) }\end{array} & \begin{array}{c}\text { Packed cell } \\ \text { volume }(\%)\end{array} \\ \text { No additions } & 100 \\ 0.20 \mathrm{M}-\mathrm{NaCl} & 79 \\ 0.14 \mathrm{M}-\mathrm{MgCl}_{2} & 82 \\ 0.30 \mathrm{M} \text {-sucrose } & 9 \mathrm{I} \\ 0.34 \mathrm{M} \text {-glycerol } & 102\end{array}$
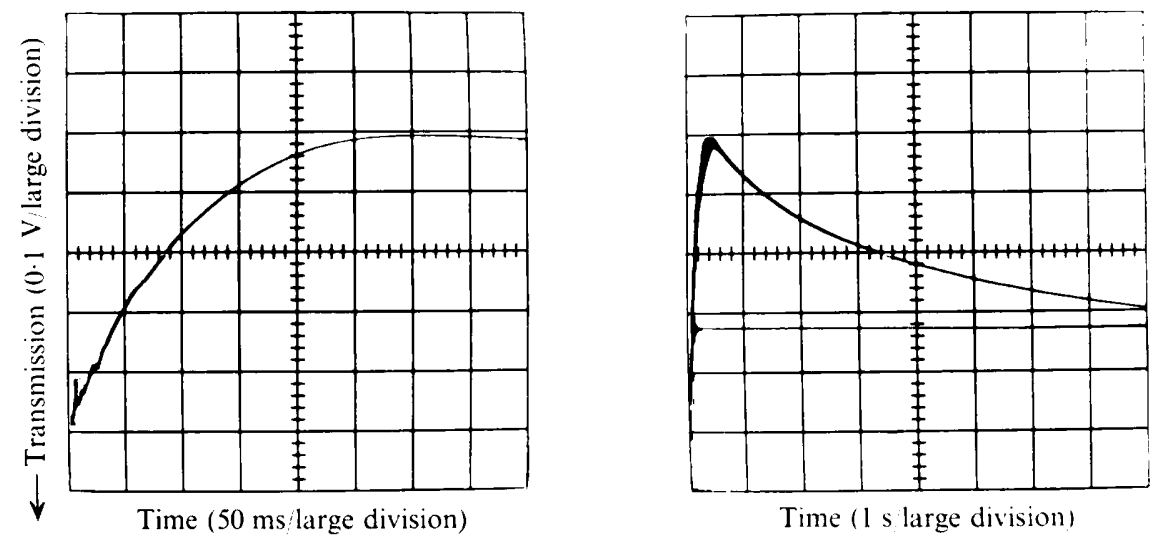

Time (1 s large division!

Fig. 4. The transient increase in turbidity of $E$. coli due to $0.5 \mathrm{M}$-glycerol. $E$. coli suspended in Io mM-imidazole buffer ( $\mathrm{pH} 7.0$ ) was mixed in a stopped-flow spectrophotometer with an equal volume of I M-glycerol in Io mM-imidazole buffer. The change in transmission was measured at $550 \mathrm{~nm}$ and the reaction temperature was $25^{\circ} \mathrm{C}$. In the left-hand trace the oscilloscope sweep rate was $50 \mathrm{~ms} /$ division and in the right-hand trace it was I s/division. The lower line in the right-hand trace was a re-sweep after a $15 \mathrm{~s}$ interval.

$60 \mathrm{~min}$ after glycerol addition. If, however, the rate of glycerol entry into the cell is slower than the osmotically induced outflow of water across the cytoplasmic membrane, then a transient decrease in cell size should occur. Since this effect is over in less than 2 min it is too rapid to measure by direct means, but it should be possible to measure the concomitant turbidity increases.

Figure 4 shows such a transient increase in turbidity on addition of $0.5 \mathrm{M}$-glycerol to cells suspended in weak buffer. There is an initial rapid increase in turbidity as water leaves the cell, followed by re-swelling (decrease in turbidity) as glycerol enters the cell. The rate of water exit is over Io times faster than the rate of the subsequent glycerol entry and the contribution of each effect to the other is small; they can therefore be considered separately.

The rate of increase in turbidity, due to water exit and cell shrinkage, is dependent on the applied osmolality (Fig. 5), confirming that this is an osmotically induced effect. The turbidity changes are not corrected for the small changes in medium refractive index due to the added $\mathrm{NaCl}, \mathrm{MgCl}_{2}$ or glycerol. It is not possible to do this experiment with sucrose as the osmotic agent owing to the large increase in medium refractive index. The effect due to glycerol is not corrected for the second phase glycerol penetration, accounting for the slightly slower apparent rates observed for this solute than for $\mathrm{NaCl}$ or $\mathrm{MgCl}_{2}$.

For cells grown on a glucose-minimal salts medium, glycerol entry, as might be expected, has first order kinetics. For each applied glycerol concentration a graph of the logarithm 


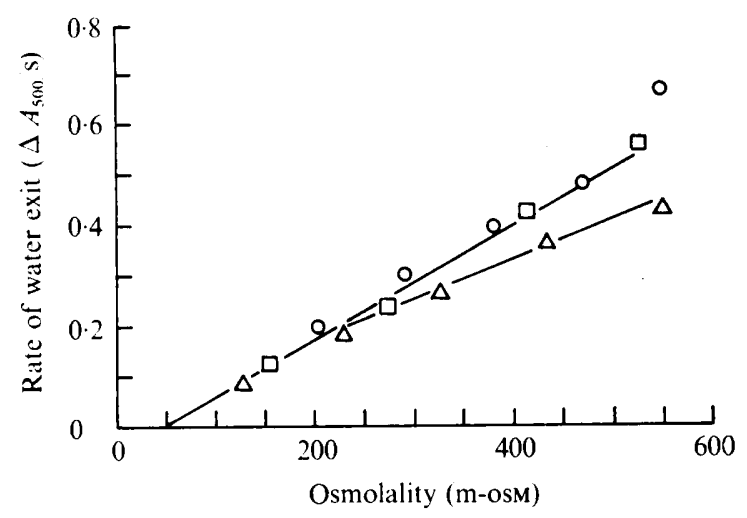

Fig. 5. The rate of increase in turbidity due to osmotically-induced water outflow from $E$. coli. Bacteria suspended in $10 \mathrm{~mm}$-imidazole buffer ( $\mathrm{pH} 7 \cdot 0$ ) were mixed with $\mathrm{NaCl}(O), \mathrm{MgCl}_{2}(\square)$ or glycerol $(\triangle)$ solutions (in ro mM-buffer) in a stopped-flow spectrophotometer at $25^{\circ} \mathrm{C}$.

of the relative decrease in absorbance against time yields a straight line plot (Fig. 6). The rate of glycerol entry is non-saturating and proportional to the applied glycerol concentration (Fig. 7). The apparent rate constant for glycerol entry is essentially constant up to a glycerol concentration of $400 \mathrm{mM}$ (Fig. 6), above that it decreases slightly; this is probably due to the increase in medium refractive index rather than indicating any saturation of the rate of glycerol entry.

The rate of glycerol entry is independent of $\mathrm{pH}$ in the range $\mathrm{pH} 5.0$ to $\mathrm{pH} \mathrm{9.0,} \mathrm{and} \mathrm{in-}$ dependent of the buffer used (provided that it is used at a low concentration, Io mM or less). The effect of temperature is shown in Fig. 8(a). Depending on the temperature range there are two different activation energies, with a distinct transition point at $2 \mathrm{I}{ }^{\circ} \mathrm{C}$. Below that there is a low activation energy of $5.0 \mathrm{kcal} / \mathrm{mol}$, whereas at higher temperatures it is greater $(13.8 \mathrm{kcal} / \mathrm{mol})$. Measurements of the rate of water exit show a similar transition point (Fig. $8 b$ ), but the activation energy below that temperature is greater than above it (I 8.3 and $8 \cdot 4 \mathrm{kcal} / \mathrm{mol}$., respectively).

Also shown in Fig. 7 is the rate of glycerol entry into the cell at different applied glycerol concentrations for cells grown on a glycerol-minimal salts medium. The straight line plot has a similar slope to that for cells grown on glucose-minimal salts medium, but the line does not pass through the zero point on the $y$-axis, and at any particular concentration of glycerol the rate of entry is much more rapid than for glucose-grown cells. Unfortunately it is not possible to measure turbidity changes at glycerol concentrations of less than about $50 \mathrm{~mm}$.

If it is assumed that, on glycerol containing media, there are two components for glycerol entry, namely non-saturating simple diffusion as found for glucose grown cells and a saturating facilitated diffusion system, then the observed rate of glycerol entry will be the sum of these two effects. The facilitated diffusion system, having a carrier protein(s), is unlikely to have a $K_{m}$ for glycerol greater than Io $\mathrm{mm}$ (as the $K_{m}$ of proteins for their substrates are rarely, if ever, greater than this, and usually very much lower). It will therefore be saturated and acting at maximal rate at glycerol concentrations of about $50 \mathrm{~mm}$ or greater. In the region of 50 to $600 \mathrm{~mm}$ glycerol, the observed rate will be due to a constant, saturated rate for the facilitated diffusion system plus an increasing rate due to simple diffusion. The line noticed should be approximately parallel to the line for the uninduced rate (Fig. 7). 


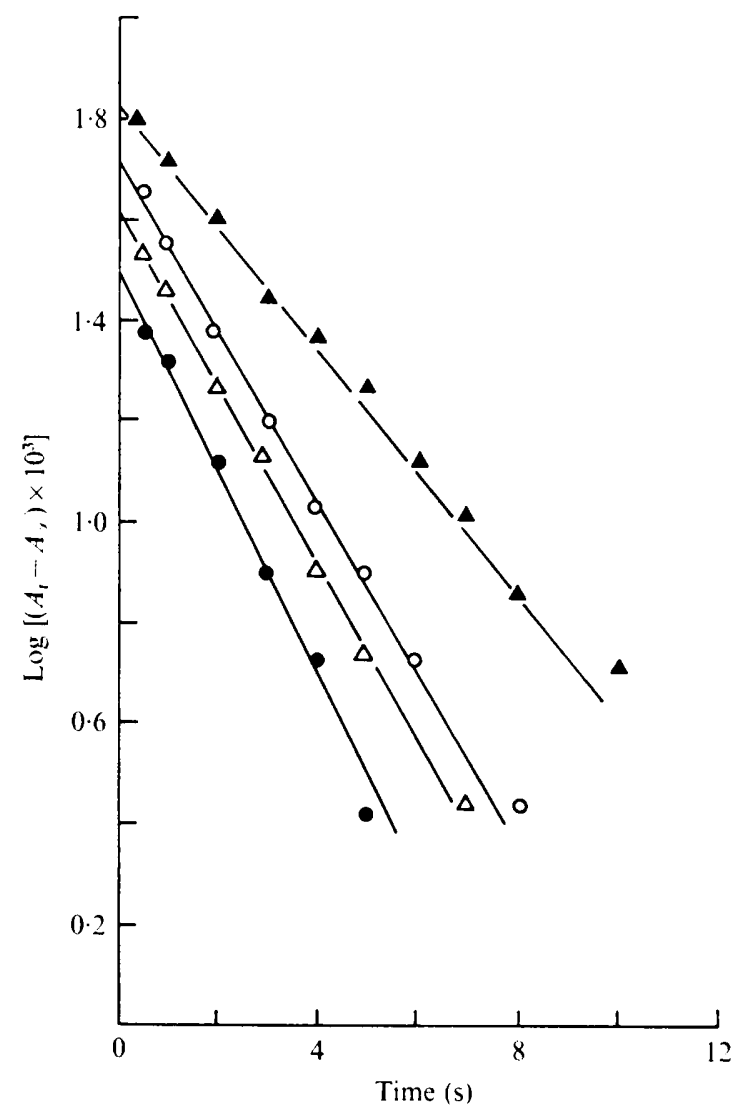

Fig. 6. The first-order kinetics of glycerol-entry into $E$. coli. Bacteria suspended in ro mm-imidazole buffer ( $\mathrm{pH} \mathrm{7 \cdot 0)}$ were mixed with glycerol (in 10 mM-buffer) to give final concentrations of $150 \mathrm{~mm}$ $(0), 200 \mathrm{~mm}(\triangle), 300 \mathrm{~mm}(O)$ or $500 \mathrm{mM}(\Delta)$ glycerol. The transient increases in turbidity were measured at $550 \mathrm{~nm}$ and at $25{ }^{\circ} \mathrm{C}$ (cf. Fig. 4). The results of the second phase (decrease in turbidity) are plotted as $\log \left(A_{t}-A_{\infty}\right)$ against time, where $A_{t}$ is the absorbance at time $t$ and $A_{\infty}$ is the final steady-state absorbance measured by a re-sweep of the signal $2 \mathrm{~min}$ after mixing. The first order rate constants were $0.44,0.41,0.40$, and $0.28 \mathrm{~s}^{-1}$ respectively.

The fact that the above effect is inducible is tentative evidence for a facilitated diffusion or active transport system for glycerol. If this is the case, then it should be possible to obtain mutants defective in the carrier system. Richey \& Lin (1972) have obtained and characterized mutants deficient in the glycerol 3-phosphate (glp) operon.

Table 4 lists the properties of some of these mutants and gives apparent rate constants for glycerol entry under various growth conditions. In induced cells the rate of glycerol entry approaches the rate of water exit, and it is not therefore possible to consider the effects (water exit, and glycerol entry plus water re-entry) as being separable. Thus, in induced cells the apparent rate constant is less than the real rate constant. In uninduced cells it should be equivalent to the real rate constant.

If the rates of water exit and glycerol entry hardly overlap, and water exit is essentially complete before glycerol entry (and water re-entry) occurs, then the maximal increase in turbidity should approach that observed using an equivalent osmolality of non-penetrant (e.g. $\mathrm{NaCl}$ ). In cells where the effects overlap appreciably the maximal increase in turbidity 


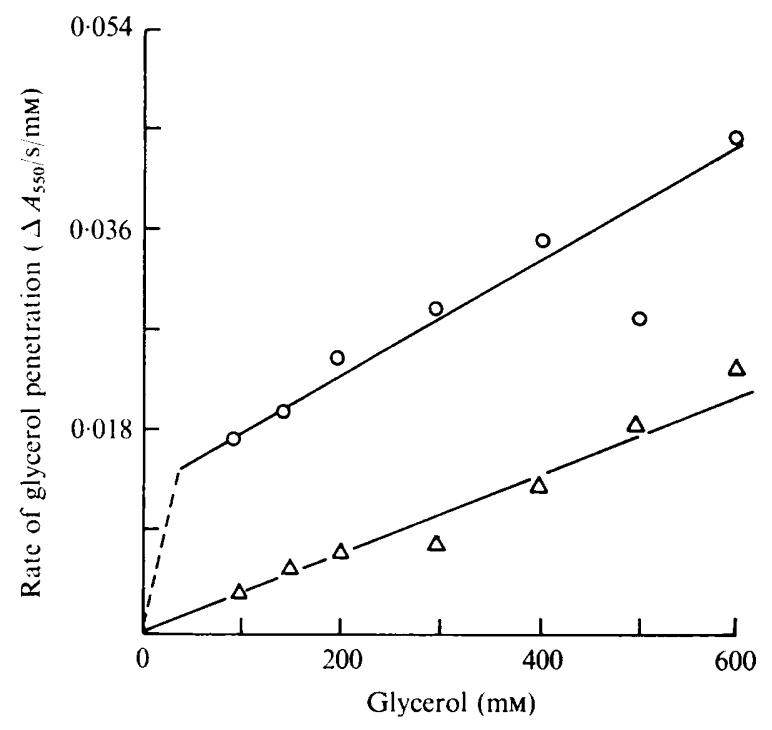

Fig. 7. The effect of concentration on the rate of glycerol entry into wild-type cells grown on media containing glucose $(\triangle)$ or glycerol $(O)$. The rates of glycerol entry were measured at $25{ }^{\circ} \mathrm{C}$ in a stopped-flow spectrophotometer. The values for the rate of entry were obtained by deriving the first order rate constant $(K)$ as given in Fig. 6.
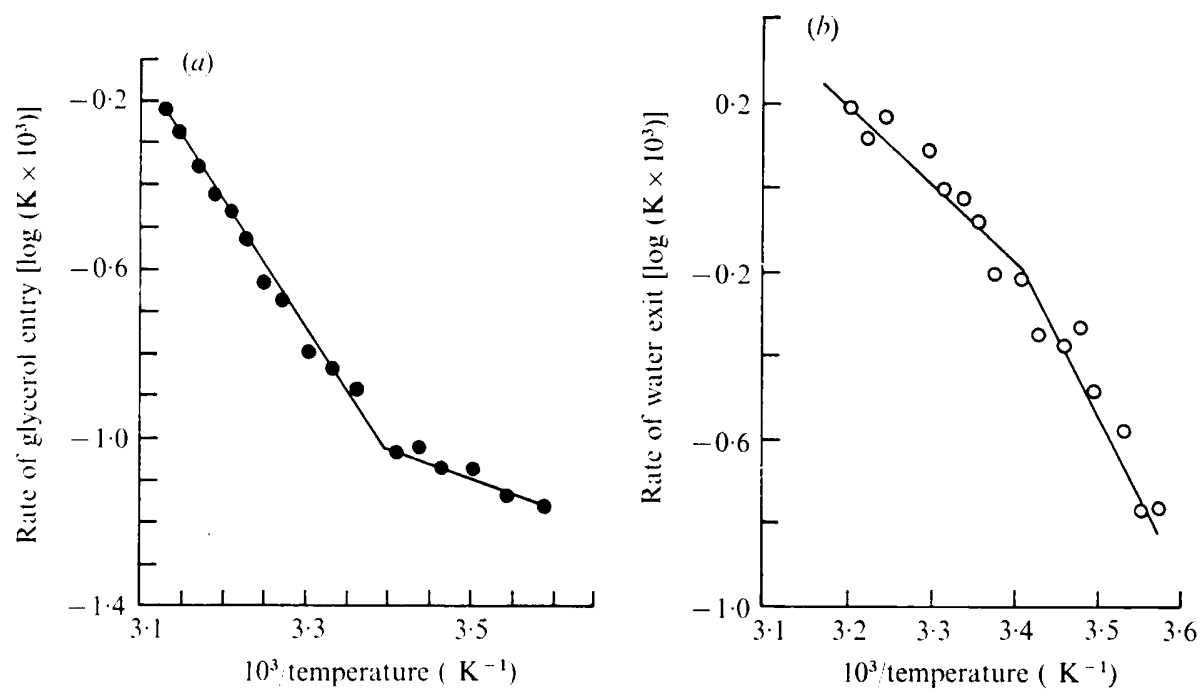

Fig. 8. Temperature dependancy of turbidity changes due to glycerol entry $(a)$ and water exit $(b)$ from E. coli. An applied glycerol concentration of $0.5 \mathrm{M}$ was used in both cases.

will be less than that observed for an iso-osmolal non-penetrant. The maximal increase in turbidity observed can therefore be used as a rough guide to the overlap of the rates.

The results are exactly as one would predict (Table 4). In glucose-grown (catabolite repressed) cells the rate of glycerol entry (expressed as the apparent first order rate constant, $K$ ) are low except in the repressor-negative strains ( 7 and 227). However, in the $\mathrm{R}^{-}$but also $\mathrm{F}^{-}$strain (229) the rate is low. In Casamino acids-grown (basal level) cells the rates are higher, except in the $\mathrm{F}^{-}$strains (229 and 282) where values are observed that are similar to those 
Table 4. The rate of glycerol entry into various mutants of $E$. coli defective in the glp gene

\begin{tabular}{|c|c|c|c|c|c|c|c|c|c|c|c|c|}
\hline \multirow[b]{3}{*}{ Strain* } & & & & & \multicolumn{8}{|c|}{ Growth substrate } \\
\hline & \multicolumn{4}{|c|}{$\begin{array}{l}\text { Genotype } † \\
\text { (glp alleles) }\end{array}$} & \multicolumn{2}{|c|}{ Glucose } & \multicolumn{2}{|c|}{ Glycerol } & \multicolumn{2}{|c|}{$\begin{array}{l}\text { Casamino } \\
\text { acids }\end{array}$} & \multicolumn{2}{|c|}{$\begin{array}{c}\text { Casamino } \\
\text { acids }+ \\
\text { glycero- } \\
\text { phosphate }\end{array}$} \\
\hline & $\mathrm{F}$ & $\mathbf{K}$ & D & $\mathbf{R}$ & $\mathrm{K} \ddagger$ & $\%$ & $\mathbf{K}$ & $\%$ & $\mathrm{~K}$ & $\%$ & $\mathbf{K}$ & $\%$ \\
\hline Wild type & + & + & + & + & 0.44 & 84 & $I \cdot 40$ & 68 & $I \cdot I 3$ & 46 & $\mathrm{I} \cdot 47$ & 42 \\
\hline I & + & + & + & + & 0.29 & 79 & $I \cdot 27$ & 54 & 0.97 & 54 & $I \cdot 3 I$ & $4 I$ \\
\hline 7 & + & + & + & - & $0.7 \mathrm{I}$ & 40 & $\mathrm{I} \cdot 93$ & 53 & $I \cdot 36$ & $5 \mathrm{I}$ & $1 \cdot 80$ & $3 I$ \\
\hline 227 & + & - & + & - & 0.74 & $5 \mathrm{I}$ & - & - & 0.53 & 40 & 0.69 & $4 \mathrm{I}$ \\
\hline 229 & - & - & + & - & 0.28 & 90 & - & - & $0.2 \mathrm{I}$ & 87 & 0.23 & $8 I$ \\
\hline 282 & - & + & + & + & 0.23 & 87 & 0.28 & 93 & 0.21 & 82 & $0.2 \mathrm{I}$ & 84 \\
\hline
\end{tabular}

* Strains I, 7, 227, 229, 282 were obtained from Dr E. C. C. Lin; the numbers of the mutants are those given by Richey \& Lin (1972).

$\dagger$ The glycerol 3-phosphate regulon (glp). F, K, D and R refer to the genes for the glycerol facilitator, glycerol kinase, glycerol 3-phosphate dehydrogenase and the repressor respectively.

$\ddagger$ The rate of glycerol entry is expressed in terms of the apparent rate constant $(K)\left(\mathrm{s}^{-1}\right)$ at $25^{\mathrm{C}} \mathrm{C}$. The experiment was performed using $250 \mathrm{~mm}$-glycerol.

$\S$ The maximal increase in turbidity expressed as a percentage of the increase observed with an equiosmolal concentration of $\mathrm{NaCl}$.

for cells grown on glucose. In cells induced for the metabolism of glycerol (glycerol or Casamino acids plus glycerol 3-phosphate-grown) the rates of entry are higher, particularly in the $\mathrm{R}^{-}$strain (7). Cells deficient in the facilitator $\left(\mathrm{F}^{-}\right)$will still grow on glycerol (due to entry by simple diffusion, cf. Richey \& Lin, 1972); clearly the rate of glycerol entry is low. Glycerol kinase negative $\left(\mathrm{K}^{-}\right)$cells do not grow on glycerol, but on Casamino acids plus glycerol 3-phosphate the facilitator system is only partially induced in the $\mathrm{K}^{-}$- strain (227). Further study of the results suggests that there is a requirement for the presence of glycerol kinase for full induction of the facilitator.

The maximal increase in turbidity for uninduced cells, with rate constants of glycerol entry of $0.5 / \mathrm{s}$ or less, is $>80 \%$ of that caused by iso-osmolal $\mathrm{NaCl}$, indicating that the processes of water exit and glycerol entry do not overlap. At higher rates of glycerol entry the maximal relative increase in turbidity is proportionately lower, in good agreement with the figures for the rate constant.

\section{DISCUSSION}

Using the exclusion (sucrose and dextran) space technique, we have shown that increases in the medium concentration of non-penetrant solutes, in addition to causing decreases in volume of the 'protoplast', cause the wall to contract, though to a somewhat lesser degree. This is presumably due to ionic interaction with the wall, since salts $\left(\mathrm{NaCl}\right.$ and $\left.\mathrm{MgCl}_{2}\right)$ cause a much greater contraction of the wall than does sucrose. These results are qualitatively similar to our earlier observations with $E$. coli (Knowles, I97I). Quantitative differences are due to the different growth conditions and phase of harvesting, as well as the more accurate technique used in the present studies.

Though it is the mechanically strong layer of the cell envelope, the wall is therefore not completely rigid and exhibits some elasticity, which may help prevent brittle fracture. It is not known whether it is the murein layer or the outer membrane that interacts with ions to 
cause decreases in volume. The fact that isolated walls of Gram-positive cells, which are principally murein and have no outer membrane, exhibit ionic contraction suggests that it is the murein rather than the outer membrane that interacts with ions (Marquis, I968; Ou \& Marquis, 1970).

Electron micrographs of plasmolysed cells (Fig. 3) show many points of adhesion between the cell wall and the cytoplasmic membrane in cells plasmolysed by salts, but not in cells plasmolysed by sucrose. This contrasts with previous studies on $E$. coli (Cota-Robles, 1963; Bayer, I $968 a, b$ ) and Salmonella typhimurium (Mühlradt, Menzel, Golecki \& Speth, I973) plasmolysed by sucrose. However, in all these studies cells were plasmolysed in media of much higher ionic strength (due to cells and added sucrose being suspended in nutrient medium or salts plus buffer). It is possible, therefore, that the maintenance of the adherence sites between the wall and the membrane depends on the ionic strength of the plasmolysing agent. So far, no experiments have been undertaken specifically to vary the ionic strength of the medium at fixed osmolalities and also measure the number of adhesion sites present.

The adherence points have been implicated as phage receptor sites (Bayer, $1968 a$ ) or as the sites of export of newly synthesized lipopolysaccharide from the inside of the cytoplasmic membrane to the outer membrane of the wall (Mühlradt et al. 1973). It will be of interest to see whether these processes are affected by the ionic strength of the medium in plasmolysed cells and whether this can be related to the number of adherence points present. It is perhaps relevant that Puck, Garen \& Cline (195I) have shown that the rate of bacteriophage attachment to $E$. coli depends on the concentration of ions in the medium.

In addition to the probable ionic interaction with the murein (Marquis, 1968), the decrease in whole cell volume could be due to the inward pull caused by the adherence points between the wall and cytoplasmic membrane as the 'protoplast' decreases in size on osmotically induced, outwards passage of water across the cytoplasmic membrane. The difference in the decrease of cell volume caused by salts and sucrose could then be explained by the lack of (or few) adherence points found in sucrose (low ionic strength)-plasmolysed cells. Further work is needed to confirm or disprove this possibility.

In Azotobacter vinelandii (Knowles \& Smith, 197I $a, b$ ), the cell wall is much more flexible than in $E$. coli and only a little plasmolysis occurs, with distinct decreases in whole cell volume induced by both sucrose and electrolytes. On the other hand, Gram-positive bacteria do not show volume changes except at very high medium osmotic pressures. This is probably due to much higher internal osmotic pressures (Marquis, 1968; Ou \& Marquis, 1970).

Despite the differences in whole cell contraction caused by salts and sucrose, the turbidity changes are strictly dependent on the applied osmotic pressure and the volume of the 'protoplast'. The turbidity changes are thus due entirely to the water movements across the cytoplasmic membrane, and are not measurably modified by the differences in the volume changes of the whole cell.

Since the turbidity changes of $E$. coli are an effective measure of the volume of the 'protoplast', they can be used to measure the penetration of solutes across the cytoplasmic membrane by simple diffusion, facilitated diffusion, or active transport.

Substrate entry into bacteria has been mainly studied by radioactivity measurements: the cells (or derived membrane vesicles) are exposed to labelled substrate, followed by filtration and assay of the radioactivity remaining associated with the cells. Radioactivity studies are more useful for investigating active transport than for facilitated or simple diffusion, since in the latter case the quantity of radioactivity in the cell is not greatly different to that of the medium and, furthermore, the intracellular volume is many times less than that of the medium. Thus, except for active transport studies, this method lacks sensitivity and is of 
limited usefulness. Assay of simple and facilitated diffusion by turbidity changes of bacteria offers a simple and rapid alternative method of study.

Accordingly we have used this technique for some preliminary studies of glycerol penetration into $E$. coli, in order to see if it is a viable technique. Glycerol penetration was selected for study because (i) entry occurs by simple diffusion and, in induced cells, by facilitated diffusion, (ii) mutants deficient in various expressions of the glp operon are available (Richey \& Lin, 1972), and (iii) the rate of glycerol entry is too rapid to measure by other techniques.

Growth on glucose media results in a non-saturating, $\mathrm{pH}$ independent penetration of glycerol by simple diffusion, which can be followed easily and conveniently in a stoppedflow spectrophotometer. Growth on glycerol media causes induction of a saturable facilitated diffusion system (Fig. 7), and the availability of facilitator negative ( $\mathrm{F}^{-}$) mutants shows that this induction is under genetic control. The inducible penetration system is much more likely to be by facilitated diffusion than by active transport because (i) appreciable accumulation of glycerol by active transport would require expenditure of enormous quantities of energy owing to the rapid loss of glycerol back to the environment by simple diffusion out of the cell, (ii) we can find no evidence, in induced cells, for accumulation of glycerol (from exclusion space experiments) to concentrations greater than that of the medium, and (iii) the inducible system for glycerol entry is not inhibited by azide, amytal, 2,4-dinitrophenol, carbonyl cyanide- $m$-chlorophenylhydrazone or fluoride. Attempts to confirm that a carrier protein is involved, by inhibition with protein reagents ( $N$-ethyl maleimide or $p$-chloromercuribenzoate) have been unsuccessful.

These results on glycerol penetration into $E$. coli confirm that measurement of turbidity changes of Gram-negative bacteria for simple and facilitated diffusion is a useful, sensitive method of assay. This technique should therefore be applicable to a wide range of similar studies.

Thermotropic lipid phase transitions (liquid crystalline - crystalline) of cytoplasmic membranes of bacteria are well documented (cf. Esfahani, Limbrick, Knutton, Oka \& Wakil, I97I, for references). The phase change occurs at temperatures somewhat below the growth temperature (Esfahani et al. I97I) and the exact transition temperature depends on the lipid composition of the membrane (Wilson \& Fox, I97I). Such phase changes affect the function of membrane-bound enzymes (Singer \& Nicolson, 1972). It is interesting, therefore, that in $E$. coli the rate of simple diffusion across the lipid phase of water and glycerol also exhibits similar transition temperatures corresponding to lipid phase transitions (Fig. 8).

Changes in activation energy of enzymes above and below the transition temperature involve proteins and associated, possibly non-bilayer and bound, non-mobile lipid (Singer \& Nicolson, 1972), and measurements of such activation energies may not be typical of the bulk-phase, mobile lipid of the membrane. Trauble \& Overath (I973) have shown that there are differences in the properties of parts of the lipid phase of $E$. coli membranes. Our observations give data for activation energies of the permeation of water and glycerol across, presumably, the mobile, non-protein associated fraction of the membrane lipids. Lipid phase transitions are therefore important with respect to functions (simple diffusion of water and solutes) of the membrane associated directly with the lipid bilayer, as well as with enzymic activity of the integral proteins.

The activation energy for glycerol permeation into $E$. coli is higher above the transition temperature than below it, yet the converse is true for water movement (Fig. 8). It is possible that this reflects the fact that in one case the water flow is out of the cell, whilst in the other the glycerol plus water movement is into the cell, i.e. the membrane exhibits sidedness. It is 
more likely, however, that the difference of effect is due to the more lipophilic properties of glycerol than water, or to their considerable difference of size and the difference in available 'holes' for their penetration (Stein, I967; cf. also Ling, 1973).

The electron micrographs were taken with the invaluable aid of $\mathrm{Dr} \mathrm{K}$. Gull and $\mathrm{Mr} \mathrm{R}$. Newsam. The stopped-flow spectrophotometer was designed by Dr B. H. Robinson and built with the aid of Dr D. A. Pugh and Mr G. S. Jackson. Mrs Pauline Collins provided excellent technical assistance. Mutant strains of E. coli were the kind gift of Dr E. C. C. Lin.

This work was supported by a grant from the Science Research Council. Some of this work was carried out whilst one of us (C.J.K.) was a Science Research Council research fellow in the laboratory of Dr D. E. Griffiths at the University of Warwick. M.M.A. was supported by scholarships from The British Council and the University of Jundi Shapor, Iran.

\section{REFERENCES}

AvI-DOR, Y., KuCZYNSKI, M., SCHATZBerg, G. \& MAGer, I. (1956). Turbidity changes in bacterial suspensions: kinetics and relation to metabolic state. Journal of General Microbiology 14, 76-83.

BAYER, M. E. (1968a). The adsorption of bacteriophages to adhesions between wall and membrane of Escherichia coli. Journal of Virology 2, 346-456.

BAYER, M. E. ( $1968 b)$. Areas of adhesion between wall and membrane of Escherichia coli. Journal of General Microbiology 53, 395-404.

Black, S. H. \& GerhardT, P. (1962). Permeability of bacterial spores. IV. Water content, uptake and distribution. Journal of Bacteriology 83, 960-967.

BLUM, R. M. \& FoRSTER, R. E. (1970). The water permeability of erythrocytes. Biochimica et biophysica acta 203, 410-423.

Bovell, C. R., Packer, L. \& Helgerson, R. (1963). Permeability of Escherichia coli to organic compounds and inorganic salts measured by light-scattering. Biochimica et biophysica acta 75, 257-266.

BRAY, G. A. (1960). A simple efficient liquid scintillator for counting aqueous solution in a liquid scintillation counter. Analytical Biochemistry I, 279-285.

ChAPPELl, J. B. \& HAARHOFF, K. N. (1967). The penetration of the mitochondrial membrane by anions and cations. In Biochemistry of Mitochondria, pp. 75-91. Edited by E. C. Slater, Z. Kaniuga and L. Wojtczak. London: Academic Press.

CотA-RoвLEs, E. H. (1963). Electron microscopy of plasmolysis in Escherichia coli. Journal of Bacteriology 85, 499-503.

EAgon, R. G. (1969). Cell wall-associated inorganic substances from Pseudomonas aeruginosa. Canadian Journal of Microbiology 15, 235-236.

EsfahanaI, M., Limbrick, A. R., KNUTton, S., OKa, T. \& WAKIL, S. J. (1971). The molecular organization of lipids in the membrane of Escherichia coli: phase transitions. Proceedings of the National Academy of Sciences of the United States of America 68, 3180-3184.

Gibson, Q. H. \& MiLNES, L. (1964). Apparatus for rapid and sensitive spectroscopy. Biochemical Journal 91, I6I-I I I.

KABACK, H. R. (1972). Transport across isolated bacterial cytoplasmic membranes. Biochimica et biophysica acta $265,367-416$.

Knowles, C. J. (197I). Salt-induced changes of turbidity and volume of E. coli. Nature New Biology 229, I54-I 55 .

KNowLES, C. J. \& SMITH, L. (I97I $a$ ). Effect of osmotic pressure of the medium on the volume of intact cells of Azotobacter vinelandii and on the rate of respiration. Biochimica et biophysica acta 234, I44-152.

KNowles, C. J. \& SMITH, L. (197I $b$ ). The relationship between substrate-induced respiration and swelling in Azotobacter vinelandii. Biochimica et biophysica acta 234, 153-161.

LiNG, G. N. (1973). What component of the living cell is responsible for its semi-permeable properties? Polarized water or lipids. Biophysical Journal r3, 807-816.

LOVETT, S. (1965). Rapid changes in bacteria following introduction into hypertonic media. Proceedings of the Society for Experimental Biology and Medicine 120, 565-569.

MATTS, T. C. \& KNowLES, C. J. (197I). Stopped-flow studies of salt-induced turbidity changes of Escherichia coli. Biochimica et biophysica acta 249, 583-587. 
MARQUIS, R. E. (1968). Salt-induced contraction of bacterial cell walls. Journal of Bacteriology 95, 775-78I.

Miller, J. H. (1972). Experiments in Molecular Genetics, p. 43I. Cold Spring Harbor: Cold Spring Harbor Laboratory.

MitChell, P. \& MoYLE, J. (1956). Osmotic function and structure in bacteria. In Bacterial Anatomy, pp. I50I80. Symposia of the Society for General Microbiology. Cambridge University Press.

MühlRadt, P. F., Menzel, J., Golecki, J. R. \& Speth, V. (1973). Outer membrane of Salmonella. Sites of export of newly synthesised lipopolysaccharide on the bacterial surface. European Journal of Biochemistry $35,47 \mathrm{I}-48 \mathrm{I}$

OU, L. T. \& MARQUIS, R. E. (1970). Electron mechanical interactions in cell walls of Gram-positive cocci. Journal of Bacteriology 101, 9I-IOI.

PuCK, T. T., GAREN, A. \& CuINe, J. (I95I). The mechanism of virus attachment to host cells. I. The role of ions in the primary reaction. Journal of Experimental Medicine 93, 65-88.

REYNOLDS, E. C. (1963). The use of lead citrate at high $\mathrm{pH}$ as an electron-opaque stain in electron microscopy. Journal of Cell Biology 17, 208-216.

RICHEY, D. P. \& LIN, E. C. C. (1972). Importance of facilitated diffusion for effective utilization of glycerol by Escherichia coli. Journal of Bacteriology 112, 784-790.

Sanno, Y., WiLson, T. H. \& Lin, E. C. C. (I968). Control of permeation to glycerol in cells of Escherichia coli. Biochemical and Biophysical Research Communications 32, 344-349.

SCHEIE, P. O. (1969). Plasmolysis of Escherichia coli B/r with sucrose. Journal of Bacteriology 98, 335-340.

SCHERRER, B. \& GERHARDT, P. (1971). Molecular sieving by the Bacillus megaterium cell wall and protoplast. Journal of Bacteriology 107, 718-735.

Sen, A. K. \& WidDAs, W. F. (1962). Determination of the temperature and pH dependence of glucose transfer across the human erythrocyte membrane measured by glucose exit. Journal of Physiology 160, 392-403.

Singer, S. J. \& Nicolson, G. L. (1972). The fluid mosaic model of the structure of cell membranes. Science, New York 175, 720-731.

SPURR, A. R. (1969). A low viscosity epoxy resin embedding medium for electron microscopy. Journal of Ultrastructure Research 26, 3I-43.

Stein, W. D. (1967). The Movement of Molecules across Cell Membranes, pp. 122-124. New York: Academic Press.

Tempest, D. W., Dicks, J. W. \& MeERs, J. H. (1967). Magnesium limited growth of Bacillus subtilis in pure and mixed cultures in a chemostat. Journal of General Microbiology 49, I39-147.

Trauble, H. \& OVErath, P. (1973). The structures of Escherichia coli membranes studied by fluorescence measurements of lipid phase transitions. Biochimica et biophysica acta 307, 49 I-5I 2.

WILson, G. \& Fox, C. F. (197I). Biogenesis of microbial transport systems: evidence for coupled incorporation of newly synthesised lipids and proteins into membrane. Journal of Molecular Biology 55, 49-60. 